\title{
FUNGSI PENDIDIKAN ISLAM DALAM KEHIDUPAN MANUSIA
}

\author{
Oleh: Muhammad Yahdi*
}

\begin{abstract}
The Almighty God blesses human with 'fitrah' (basic competence) to play their role as the most noble creature. Human can observe their nature and it may lead them to perfection. Misbehaved human are those who do not understand the meaning of 'fitrah' correctly. Fitrah controls all human activities and behaviours in the community. This is the reason why human should do something advantageous and be advantageous to others.
\end{abstract}

KEYWORDS: Fitrah, pendidikan Islam, manusia

PENDIDIKAN dan pendidikan Islam khususnya mempunyai peran dan fungsi penting dalam pertumbuhan dan perkembangan anak didik. Pendidikan mempengaruhi seluruh sisi peserta didik, aspek pengetahuan yang melingkupi, ketajaman mengingat, memahami, menganalis, mensintesis, mengevaluasi. Bukan hanya pada aspek itu, akan tetapi juga pada sisi afeksi peserta didik yaitu pengenalan dan penghayatan terhadap nilai tertentu aspek yang bersumber dari nilai agama dan nilai budaya masyarakat.

Kepentingan seperti yang tersebut di atas, sangat memungkinkan bagi manusia sebagai peserta didik, disebabkan oleh karena manusia memiliki potensi untuk dapat ditumbuhkembangkan melalui potensi fitrahnya. Fitrah bukan semata seperti yang dipahami oleh masyarakat umum, yaitu suci akan tetapi terjadinya perubahan pada diri seseorang termasuk peserta didik disebabkan oleh fitrah yang dimilikinya.

Fitrah itulah yang dapat mengembangkan intelegensi, emosional, religius, sosial, dan kompetensi pribadi sebagai keunikan setiap orang. Seseorang yang dinilai cerdas dalam ilmu apapun yang dimilikinya sangat terkait dengan fitrahnya. Fitrah menjadi pusat segala kegiatan yang dilakukan manusia baik dalam interaksi dengan dirinya maupun interaksi sosial.

*Kandidat doktor dalam bidang Pendidikan Islam pada Program Pascasarjana Universitas Islam Negeri Alauddin ini adalah dosen tetap Fakultas Tarbiyah dan Keguruan UIN Alauddin Makassar. 
Dalam konteks Islam fitrah sebagai pusat perubahan, memiliki muatan yang sangat besar, bebannya yang berhubungan dengan aspek mental dengan bagian-bagian yang beraneka ragam; memiliki aspek berpikir, emosi, sosial, individu, moralitas, spiritual, dan agama. Sedangkan pada aspek fisik adalah yang berhubungan dengan struktur fisik manusia. Kedua aspek tersebut menjadikan manusia sebagai makhluk yang unik, membedakan antara manusia dengan makhluk lain, memiliki kesem-purnaan yang sangat berbeda dengan makhluk lain. Islam menempatkan manusia sebagai ciptaan yang kepadanya dibebankan amanah sebagai khalifah karena kesempurnaan yang diberikan oleh Allah Swt.

\section{FUNGSI-FUNGSI PENDIDIKAN ISLAM}

Pendidikan dan pendidikan Islam khususnya memiliki fungsi penting. Pendidikan diakui sebagai satu kekuatan (education of power) yang menentukan prestasi dan produktivitas di bidang lain". ${ }^{1}$ Sebagai satu kekuatan berarti pendidikan mempunyai kewenangan yang cukup kuat bagi rakyat banyak untuk menentukan suatu dunia atau arah kehidupan yang pasti. Dapat dikatakan bahwa seseorang tidak memiliki fungsi dalam kehidupan masyarakat tanpa melalui proses pendidikan.

Pendidikan Islam memiliki keunikan yang tidak dimiliki pendidikan lain, dapat menumbuhkan kecerdasan intelektual, spiritual, emosional, dan sosial. Fungsi tersebut berjalan seiring dengan petumbuhan dan perkembangan yang dialami oleh setiap orang. Karena itu pendidikan Islam tidak mengenal, kelompok usia tertentu, kelompok sosial tertentu, dan lingkungan pekerjaan tertentu. Akan tetapi pendidikan dapat mengikuti irama masyarakatnya. Adapun fungsi pendidikan Islam yaitu: menumbuhkan kecerdasan emosional.

Untuk memudahkan memahami kecerdasan emosional, penulis memilah kecerdasan dan emosional. Kecerdasan berasal dari kata cerdas yang berarti sempurna perkembangan akal budinya, pandai, dan tajam pemikirannya. ${ }^{2}$ Cerdas dapat pula bermakna sempurna pertumbuhan tubuhnya seperti sehat dan kuat fisiknya" 3 Sedangkan kata emosional berasal dari bahasa Inggris, emotion yang berarti keibaan hati, suara yang mengandung emosi, pembelaan yang mengharukan, pembelaan yang penuh perasaan" 4 dalam perkembangan menjadi kecerdasan emosional (emosional intellegensi).

Kecerdasan emosional mengandung beberapa makna yaitu Pertama, kecerdasan emosi tidak hanya berarti bersikap ramah, melainkan sikap tegas, mengungkapkan kebenaran yang selama ini dihindari, Kedua, kecerdasan emosi bukan berarti memberikan kebebasan kepada perasaan 
untuk berkuasa memanjakan perasaan, melainkan mengelola perasaan sedemikian sehingga terekspresikan secara tepat dan efektif, yang memungkinkan orang bekerjasama dengan lancar menuju sasaran bersama, Ketiga, kepiawaian, kepandaian dan ketepatan seseorang dalam mengelola diri sendiri dalam hubungannya dengan orang lain di sekeliling mereka dengan menggunakan seluruh potensi psikologis yang dimilikinya seperti; inisiatif, empati, kemunikasi, kerja sama dan kemampuan persuasi" 5

Kecerdasan emosional apabila dihubungkan dengan pendidikan Islam akan ditemukan istilah insan yang menunjuk manusia secara totalitas, jiwa, dan raga. Manusia berbeda dengan manusia lain, dari segi fisiknya, mental, dan kecerdasannya. Insan bisa bermakna melihat, mengetahui, meminta izin.

Dengan menggunakan kata insan, dapat diketahui bahwa kecerdasan emosional adalah kemampuan dan kecakapan manusia dalam memanfaatkan potensi psikologisnya, seperti kemampuan dalam bidang penalaran, memanfaatkan waktu luang, mengatur waktu, berkomunikasi, beradaptasi dan keterkaitan dengan moral. Bila semua potensi dimanfaatkan, dikembangkan, dan dikelola, maka manusia akan menemukan dirinya sebagai makhluk yang bermartabat dan berada dalam posisi yang membahagiakan baik di dunia maupun di akhirat.

Kecerdasan emosional menjadi penting dalam menopang kelangsungan dan kesuksesan manusia dalam menjalani tugasnya. Bilamana dihubungkan dengan dunia kerja, kecerdasan emosional adalah prestasi puncak dalam pekerjaan. Untuk itu para pelatih saat ini banyak mengatakan bahwa kecerdasan emosional harus menjadi alasan mendasar dalam setiap pelatihan manajemen. Dengan cara demikian semakin terbuka berbagai kemungkinan yang dapat membawa kesuksesan.

Dalam pendidikan Islam berbagai ciri yang menandai kecerdasan emosional terutama dalam pendidikan akhlak. "Pendidikan Islam adalah pendidikan yang memberikan bimbingan jasmani dan rohani menuju terbentuknya kepribadian utama menurut ukuran-ukuran Islam"6 Dalam pandangan lain dikemukakan oleh Saefuddin Anshari, "bahwa pendidikan Islam adalah proses bimbingan (pimpinan, tuntunan, usulan) oleh subyek didik terhadap perkembangan jiwa (pikiran, perasaan, kemauan, intuisi dan sebagainya) dan raga obyek didik dengan bahan materi, metode tertentu dengan alat perlengkapan yang ada ke arah terciptanya pribadi tertentu disertai evaluasi sesuai dengan ajaran Islam". ${ }^{7}$

Berbagai pendapat seperti yang disebutkan diatas, memperlihatkan betapa sempurnanya pendidikan Islam. Paling tidak dapat dikatakan bah- 
wa pendidikan Islam di samping berupaya membina kecerdasan intelektual, keterampilan dan raganya juga membina jiwa dan hati nuraninya. Pembinaan intelektual dilakukan dengan memberikan mata pelajaran yang berkaitan dengan akal pikiran dan pembinaan keterampilan dengan memberikan latihan-latihan dalam mempergunakan berbagai peralatan, sedangkan pembinaan jiwa dan hati nurani dilakukan dengan membersihkan hati nurani dari penyakit hati seperti; sombong, congkak, dendam, iri hati, dan sebagainya, serta dengan mengisi nilai-nilai akhlak yang terpuji serperti; ikhlas, jujur, kasih dan sayang, tolong menolong, bersahabat, bersilaturrahmi, berkomunikasi, dan saling mengingatkan.

Pendidikan akhlak memang sangat penting, dalam kehidupan individu dan sosial. Meskipun pendidikan akhlak saat ini semakin sulit ditumbuhkan. Pendidikan pada umumnya dan pendidikan Islam khususnya saat ini cenderung berhasil membina intelektual dan tenaga terampil namun kurang berhasil dalam menumbuhkan kecerdasan emosional. Hal tersebut terjadi disebabkan karena; Pertama, pendidikan yang diselenggarakan cenderung bersifat pengajaran bukan pendidikan, padahal pendidikan dan pengajaran harus diintegrasikan. Kedua, pendidikan saat ini sudah berubah orientasi nilai dan idealisme yang berjangka panjang, kepada yang bersifat materialisme dan individualisme yang mementingkan tujuan jangka pendek, Ketiga, metode pendidikan yang diterapkan tidak bertolak pada pandangan dengan melihat manusia sebagai makhluk yang paling mulia dan memiliki potensi yang bukan hanya potensi intelektual (akal), tetapi juga potensi emosional. Metode pendidikan yang diterapkan lebih melihat murid sebagai gelas kosong yang dapat diisi oleh guru dengan sekehendak hati, dan bukan melihat sebagai makhluk yang memiliki berbagai potensi yang harus ditumbuhkan, dibina, dikembangkan dan diarahkan, Keempat, Pendidikan Islam kurang mengarahkan siswa untuk mampu merespons berbagai masalah aktual yang muncul di dalam masyarakat, sehingga terdapat kesenjangan antara dunia pendidikan dengan kehidupan masyarakat.

\section{MANUSIA MEMILIKI FITRAH/POTENSI}

Manusia selalu menarik dikaji, selain manusia sendiri juga karena pikiran yang dimiliki manusia yang tidak sampai menembus hakekat manusia, boleh jadi manusia enggan sampai kepada kesempurnaannya. Memikirkan tentang manusia semenjak pada filosof dengan mengaitkan dinamika alam yang ada disekitarnya. Thales dengan teori semuanya air. Air yang cair adalah pangkal, pokok, dan dasar dari segalanya. Memahami manusia semata dengan akal. Thales yang melihat masyarakat Mesir setiap 
hari hidup dengan air sungai nil, airlah yang menyuburkan tanah. Bila tidak ada sungai nil maka Mesir adalah hamparan padang pasir. Air dilihatnya pasang surut sewaktu air menggulung dan menghanyutkan, di sinilah dihapuskannya segala hidup" ${ }^{\prime}{ }^{2}$

Betapa manusia mengalami kemajuan yang persentuhan dengan sekitarnya, "masyarakat Yunani Kuno mengalami hidup Protogeometrik aniconic sebuah teknologi (Athena $1050 \mathrm{SM}$ ) penggunaan banyak kuas yang disematkan pada jangka dan ini menjadi sebuah penemuan di Athena, yang lebih pantastis lagi adalah illustrasi pengenalan manusia dan kuda dalam dekorasi vas geometric. Wawasan ini menjadi kelaziman dilembah Aigen selama berabad lamanya" ${ }^{9}$

Potensi kejiwaan manusia yang mendominasi perubahan manusia, tidak ditemukan oleh pergerakan pemikiran Thales, meskipun dalam dirinya terjadi perubahan tetapi tidak diketahuinya. Unsur kejiwaan yang mengantar manusia ke alam sadar. Sadar akan banyak cakupan makna tergantung kapan mengucapkannya. Seseorang yang baru bangun tidur akan mengatakan saya baru sadar, orang yang salah dalam berkata, dengan ketahuannya itu akan mengatakan baru sadar dan mohon maaf. Pada umumnya pekataan sadar diucapkan manusia diikuti dengan ucapan maaf. Menurut Arnold benarlah bahwa "seorang makhluk yang sadar dapat menjadi jahat, sedangkan makhluk yang tidak sadar tidak demikian. Seorang makhluk yang sadar bisa menjadi baik, selain menjadi jahat; makhluk non sadar tidak dapat menjadi jahat maupun baik. Bagi makhluk non sadar perbedaan etis antara kejahatan dan kebaikan tidak dan tidak mungkin ada. Pertama-tama etik muncul dibiospir bersamaan dengan kesadaran. Secara bersamaan pula, kesadaran dan etik menyatakan sebuah model eksistensi model spiritual yang sebelumnya tidak terpresentasikan di biospir ini. Manusia dalam ranah pendahulunya bisa saling diperbandingkan dalam ranah biologis, dan dalam ranah ini, apiliasi manusia dengan nenek moyangnya dapat diketahui dan ditelusuri, tetapi pada ranah etis tidak ada kesamaan karena ranah etis hanya ada pada makhluk sadar"10

Peristiwa yang menandai kemunculan manusia pertama di biospir bukanlah perkembangan manusia anatomisnya atau prestasi karyanya, tonggak peristiwa histori ini adalah bangkitnya kesadaran manusia. Waktu terjadinya peristiwa ini hanya dapat diduga dengan jejak material yang ditinggalkan oleh nenek moyang. Tidak ada dan tidak mungkin ada yang namanya kesadaran kontemporer atas sesuatu pengalaman, dan konsekuensinya tidak ada nada catatan apapun tentangnya. Seseorang manusia sadar bahwa dirinya sadar ketika dia terbangun, tetapi dia tidak secara 
sadar menangkap dirinya yang sedang berusaha bangun atau sedang tidur. Oleh karena itu tidak dapat melakukan hal lain kecuali menduga waktu ketika manusia terbangun menjadi sadar dengan mengamati perkembangan anatomisnya dan prestasi sosial serta teknologi yang khas.

Biospir dan kesadaran dua hal yang sangat berlawanan, keduanya berada dalam alam yang berbeda. Tetapi keduanya tidak bisa dipisahkan karena di dalam alam sadar, berarti biospir sebaliknya di alam biospir akan melahirkan kesadaran. Kesadaran menjadi penting, karena dalam kemajuan umat manusia sangat ditentukan oleh kualitas kesadarannya. Perjalanan peradaban dunia setelah melewati fase yang sangat panjang dan berliku, semenjak zaman Thales (filosof pertama dan alam) sampai kepada peradaban Meso Amerika yang hadir dengan ketakjubannya. Di dunia Meso Amerika disebut juga dengan fase klasik, yang mencapai puncak kejayaannya pada tahun 300-600 M. selama tiga abad, kota Teotihuacan berkembang peradaban model Maya adalah sebuah bangunan megah dengan lukisan yang menakjubkan memperlihatkan kekejaman menyerupai Assyria yang dilakukan terhadap tawanan-tawanan perang. Dalam lukisan ini digambarkan, bahwa masyarakat menghancurkan dirinya sendiri dengan melakukan perang saudara.

Manusia sesungguhnya tidak bisa terpisah dengan alam. Dipermukaan bumi terdapat banyak benda, ada benda mati dan benda hidup. Manusia dapat digolongkan sebagai makhluk sejenis binatang terutama dari segi jasmani. Meskipun sebagian dari konstrtuksi jasmaninya terdapat perbedaan asasi. Karena itu, maka Allah menyebut manusia adalah makhluk ciptaan yang paling baik dari segi jasmani maupun rohaninya (QS. At Tin:4).

Dari hubungan timbal balik dengan orang-orang dan alam disekitarnya, maka terjadilah rangsangan-rangsangan yang dapat memperkembangkan potensi-potensi alamiah manusia. Hasil potensi manusia dapat berbudaya, berkarya dan mencipta. Demikian pula masyarakat baru dapat berbudaya atau berkarya setelah mengadakan pergaulan dengan masyarakat lain.

Dalam kedudukan manusia seperti di atas, (terjadinya perubahan) setelah mengadakan interaksi dengan sesama manusia dan alam sekitar, karena manusia memiliki fitrah. Dalam menelusuri manusia dari segi kejiwaan terdapat perbedaan yang mencolok terutama apabila dikaitkan dengan sudut pandang Islam. Dalam konteks nativisme manusia dipandang memiliki bawaan dan sudah ada sejak lahir. Manusia tumbuh dan berkembang bukan karena lingkungan sekitarnya akan tetapi karena sifat bawaan (hereditas) yang di bawahnya. Ada pula yang disebut dengan 
empirisme yaitu pandangan bahwa manusia tumbuh dan berkembang karena pengalaman atau realitas sosial. Perubahan alami manusia karena dibentuk oleh lingkungan sekitarnya. Apabila lingkungan sekitar baik, maka akan lahir sikap dan kepribadiannya menjadi baik. Demikian pula sebaliknya apabila lingkungan sekitarnya buruk maka manusia akan dibentuk menjadi pribadi yang buruk. Sedangkan yang lain adalah konvergensi yaitu pandangan yang mengatakan bahwa manusia dapat dipengaruhi oleh faktor bawaan dan lingkungan sekitar. Ternyata pandangan-pandangan dengan egoismenya saling mengkritik dan mempertahankan. Harus diakui bahwa sebuah teori yang dilahirkan oleh manusia akan memiliki semangat dan maksud tertentu. Disamping itu teori yang dikeluarkan pasti memiliki kelebihan dan kelemahan disaat terinteraksikan dengan realitas sosial. Karena itu teori yang dihasilkan oleh manusia syarat dengan kekeliruan dan kekurangan baik dalam sudut pandang manusia secara pribadi maupun sosial.

Selain dari pada itu, manusia adalah makhluk fitrah. Hal tersebutlah titik awal perbedaan antara manusia dengan makhluk lain. Kesempurnaan yang dimiliki manusia, karena memiliki fitrah.

Fitrah berasal dari kata fatrh yang berarti belahan, penciptaan atau kejadian. Kata tersebut disebut dalam Al-Qur'an (Q.S. al-Rum: 30) yang artinya; maka hadapkanlah wajahmu dengan lurus kepada agama (Allah); tetaplah atas fitrah Allah yang telah menciptakan manusia menurut fitrah itu. Tidak ada perubahan pada fitrah Allah (itulah) agama yang lurus; tetapi kebanyakan manusia tidak mengetahuinya." Fitrah juga disebut bentuk dan sistem yang diwujudkan Allah pada setiap makhluk. Fitrah berkaitan dengan manusia adalah apa yang diciptakan Allah pada manusia yang berkaitan dengan jasmani dan akalnya". ${ }^{11}$ Fitrahpun bermakna terbukanya sesuatu dan melahirkannya". ${ }^{12}$ Fitrah berarti al-insyiqaq atau al-syaqq yang berarti alinkisar (pecah belah) bisa pula bermakna penciptaan"13 Secara etimologis, fitrah adalah citra asli yang dinamis, yang terdapat pada sistem-sistem psikofisis manusia dan dapat diaktualisasikan dalam bentuk tingkah laku. Citra tersebut telah ada sejak awal penciptaannya. ${ }^{14}$

Manusia merupakan makhluk mikro kosmos dan miniatur alam yang kompleks. Fisiknya menggambarkan alam fisikal, sedangkan psikisnya menggambarkan alam kejiwaan. Segala proses adalah takdir atau sunnatullah yang berlaku pada alam sebenarnya juga berlaku pada manusia seperti konsep penciptaan. Kompleksitas yang dimiliki manusia yang membuat manusia dapat tumbuh dan berkembang sesuai dengan irama perkembangan manusia dan peradaban di sekitarnya. Sebagai makhluk yang kompleks, manusia dilengkapi dengan potensi lain yaitu; a) ruh (Q.S. 17: 85) 
yang menggambarkan bahwa ruh yang dimiliki manusia adalah merupakan campur tangan Tuhan, manusia tidak perlu untuk mencampurinya. Apa, mengapa, bagaimana, dan mengapa ruh ada pada manusia sesungguhnya rahasia Tuhan (Allah). Ruh adalah himpunan yang terorganisasi, yang saling mengenal akan bergabung dan yang tidak saling mengenal akan saling berselisih" 15 Karena itu pada diri manusia terdapat keanekaragaman, manusia mempunyai kecenderungan yang berbeda-beda, dan setiap kecenderungan jiwanya akan bergabung dengan sesama, b) Aql (akal), akal mengandung arti dorongan untuk memahami dan menggambarkan sesuatu, dorongan moral dan daya upaya mengambil pelajaran dan kesimpulan serta hikmah".16

Memahami fitrah yang lebih luas, yang berkaitan dengan dimensi spiritual, sosial dan kompetensi individu dapat dilihat pada beberapa hal berikut ini;

Pertama, fitrah berarti suci. Nabi Muhammad saw. bersabda yang artinya; "setiap anak tidak dilahirkan dalam kondisi fitrah (suci), maka kedua orang tuanyalah yang menjadikannya Yahudi, Majusi atau musyrik" (HR al-Bukhari). Konteks tersebut dapat dipahami bahwa manusia yang memiliki kesucian bukan hanya anak yang dilahirkan dalam komunitas muslim akan tetapi dari komunitas siapa saja, sesungguhnya memiliki potensi kesucian. Suci dalam makna ini, bukan manusia dalam keadaan kosong seperti yang ditemukan dalam teori John Locke "melainkan suci dari dosa warisan dan penyakit ruhaniah"17

Kedua, Fitrah berarti potensi ber-Islam. Pemaknaan tersebut menunjukan bahwa tujuan diciptakannya manusia adalah penyerahan diri kepada yang mutlaq (Islam) tanpa ber-Islam berarti kehidupan telah berpaling dari fitrah asalnya.

Ketiga, fitrah berarti pengakuan keesaan Allah. Manusia lahir dengan membawa potensi tauhid, ia berkecenderungan untuk mengesakan Allah, dan berusaha secara terus menerus untuk mencari dan mencapai keTauhidan yang sebenarnya. Manusia secara fitrah memiliki watak walaupun masih dalam immateri (Q.S. al-A'raf: 172).

Keempat, fitrah selamat (al-salamah) dan kontinuitas. Fitrah secara potensial berarti keselamatan dalam proses penciptaan, watak dan strukturnya. Iman dan kufurnya baru tumbuh setelah manusia mencapai akil baliq, sebab ketika masih bayi atau anak-anak, mereka belum mampu berpikir apalagi menerima keberadaan Tuhan.

Kelima, fitrah kesanggupan atau predisposisi untuk menerima kebenaran. Secara fitriah manusia lahir cenderung berusaha mencari dan menerima kebenaran, walaupun pencarian itu masih tersembunyi di dalam 
lubuk hati yang paling dalam. Adakalanya manusia telah menemukan kebenaran, namun karena faktor eksternal yang mempengaruhiunya, maka ia berpaling dari kebenaran.

Keenam, fitrah tulus (ikhlas). Manusia lahir dengan membawa sifat baik. Diantara sifat itu adalah ketulusan dan kemurnian dalam melakukan kreasi. Pemaknaan tulus ini merupakan konsekuensi fitrah manusia yang harus berpotensi ber-Islam dan ber-Tauhid. Sebab dengan ber-Islam berarti seseorang telah menghambakan diri kepada zat yang mutlaq yaitu Allah Swt. dan menghilangkan segala dominasi sesuatu yang temporal atau nisbi.

Ketujuh, fitrah dasar manusia atau perasaan untuk beribadah dan ma'rifah kepada Allah. Dalam pemaknaan ini, aktivitas manusia merupakan tolok ukur pemaknaan fitrah. Manusia diperintahkan untuk beribadah agar dia mengenal Allah. Pengenalan merupakan indikator kefitraan manusia. Hal itu disebabkan bahwa fitrah merupakan watak asli manusia, watak dapat terlihat melalui aktivitas tertentu yaitu ibadah.

Kedelapan, fitrah tabiat atau watak. Watak atau tabiat merupakan daya dari daya nafs kulliyah yang menggerakan jasad manusia. Maka inilah yang lebih tepat untuk mengungkap pembagian, natur dan aktivitas fitrah. Secara sederhana kedua kata tersebut dapat dibedakan (fitrah dan watak) yaitu; kata fitrah merupakan potensi bawaan yang berlabel Islam dan berlaku untuk semua manusia. Sedangkan tabiat "merupakan sesuatu yang ditentukan atau ditulis oleh Allah melalui ilmunya"18 atau dengan kata lain fitrah manusia pasti sama, yaitu ber-Islam tetapi tabiaatnya berbeda-beda. Fitrah lebih luas cakupannya dari pada tabiat.

Terdapat kehidupan keseimbangan yang dimiliki manusia berupa potensi beribadah, berserah diri kepada Allah, dalam hal lain, manusia memiliki sifat untuk melakukan pembangkangan atau perusakan dalam kehidupan sesama. Allah berfirman dalam surah al-Baqarah ayat 30, artinya; Ingatlah ketika Tuhanmu berfirman kepada para malaikat; sesungguhnya Aku hendak menjadikan seseorang khalifah dimuka bumi. Mereka berkata; mengapa Engkau hendak menjadikan (khalifah) dimuka bumi itu orang yang akan membuat kerusakan padanya dan menumpahkan darah, padahal kami senantiasa bertasbih dengan memujimu dan mensucikan Engkau. Tuhan berfirman; sesungguhnya Aku mengetahui apa yang tidak kamu ketahui".

Dari gambaran di atas dapat dipahami bahwa manusia memiliki citra baik, juga menunjukkan superioritas manusia dibanding dengan malaikat. Malaikat terstruktur sebagai makhluk yang baik dan ia melakukan kebaikan itu sepanjang hidupnya tanpa melakukan penyelewengan atau penyim- 
pangan. Berbeda dengan jenis manusia yang diberi potensi baik atau buruk dan dibebaskan untuk memilih dan mengaktualisasikan dalam kehidupannya, apakah manusia memilih mengembangkan potensi baik sehingga ia menjadi makhluk yang baik ataukah ia mengembangkan potensi yang buruk sehingga ia menjadi makhluk yang buruk.

Kalaupun ada ungkapan bahwa manusia itu adalah hewan yang berpikir. Secara substantive, ungkapan tersebut sesungguhnya salah dan menyalahi konsepsi manusia yang hakiki. Manusia dipahami sebatas pada substansi fisiknya, tanpa dikaitkan dengan substansi ruhaniahnya. Kedirian dan kesendirian fisik manusia hampir sama fungsinya dengan hewan sehingga manusia dapat disebut sebagai hewan.

Manusia bukanlah entitas yang homogen, tetapi suatu kenyataan yang heterogen yang tak jarang carut marut yang tidak teratur. Paling tidak bahwa kehidupan manusia adalah suatu kehidupan yang kompleksnya tinggi dibandingkan dengan makhluk lain. Meskipun demikian secara khusus manusia dapat dipahami dan didekati dari segi substantif. Secara sederhana dapat dilihat kedirian manusia sebagai berikut; 1) Manusia mempunyai derajat yang tinggi sebagai khalifah Allah dibumi, 2) Manusia tidak mengandung dosa asal atau dosa turunan, 3) Manusa merupakan kesatuan dari empat dimensi yaitu; fisik-bioligis, mental-psikis, sosiokultur, dan spiritual, 4) Dimensi spiritual memungkinkan manusia mengadakan hubungan dan mengenal Tuhan melalui cara yang diajarkan-Nya, 5) Manusia memiliki kebebasan berkehendak (freedom of will) yang memungkinkan manusia untuk secara sadar mengarahkan dirinya kearah keluhuran atau kesesatan, 6) Manusia memiliki akal sebagai kemampuan khusus untuk mengembangkan ilmu dan peradaban, 7) Manusia tidak dibiarkan hidup tanpa bimbingan dan petunjuk Allah.

\section{MANUSIA DAPAT DIDIDIK DAN MENDIDIK}

Manusia adalah makluk sosial seperti dalam ulasan sosiologis, tidak terpisah dengan manusia dan makhluk lain. Pertumbuhan dan perkembangan ditentukan oleh interaksi yang dilakukan dalam lingkungan masyarakatnya. Dalam konteks pendidikan peserta didik adalah subyek dan obyek pendidikan. Karena itu dalam proses pendidikan peserta didik harus diketahui, mulai dari latar belakangnya, dan perubahan-perubahan yang telah dilewati. Peserta didik adalah sumber daya manusia yang memerlukan pendidikan. Makna memerlukan tidak hanya diartikan yang bersangkutan memiliki pemahaman dan kesadaran untuk memperoleh suatu pendidikan, namun lebih jauh dari itu adalah setiap orang, setiap anak atau setiap sumber daya manusia yang menurut konstitusi kultural, 
sosial dan individual seharusnya memperoleh pendidikan. Dengan demikian peserta didik tidak hanya diartikan sebagai mereka yang berusia muda, mereka yang secara biologis siap dan sedang berkembang, tetapi setiap orang yang belum dewasa baik secara fisik maupun mental. Seorang intelek dengan latar belakang pendidikan tinggi yang sedang mempelajari pengetahuan dan keterampilan tertentu dipandang belum dewasa pada aspek atau bidang yang sedang dipelajarinya, sehingga yang bersangkutan disebut dengan peserta didik"19

Dalam Al-Qur'an Allah menggambarkan peserta didik dalam surah an-Nahl: 78, yang menggambarkan bahwa peserta didik itu adalah mereka yang memiliki ilmu pengetahuan dan kepribadian, karena ketika dilahirkan mereka tidak membawa bekal pengetahuan, keterampilan dan kepribadian yang dibutuhkannya kelak. Hal yang dimiliki oleh setiap orang adalah fitrahnya sebagai potensi yang dapat ditumbuhkembangkan dari sederhana menjadi kompleks.

Oleh karenanya, maka hakekat peserta didik bisa juga manusia dewasa baik dari biologis maupun psikologis dalam aspek bidang tertentu yang masih memerlukan atau sedang mempelajari, mengembangkan bidang pengetahuan dan keterampilan tertentu guna memenuhi kebutuhan kehidupan umat manusia" 20

Dari hal tersebut di atas, dapat dipahami bahwa manusia akan terdorong untuk mempelajari pengetahuan dan keterampilan tertentu dalam rangka memakmurkan, mengelola dan memenuhi kebutuhan hidup manusia bersangkutan, juga menegaskan kepada manusia bahwa hidup ini dipertanggungjawabkan, sehingga diperlukan kemampuan/pengetahuan tertentu guna mengembangkan diri sebagai basis perkembangan peradaban manusia, sebuah masyarakat pada zaman tertentu, akan sangat menentukan corak peradabannya sebagai cermin generasi berikutnya. Apabila masyarakatnya secara personal dan kolektif memiliki pengetahuan dan keterampilan yang banyak seperti itu pula corak dan kemajuan peradaban yang hidup tumbuh dan berkembang dalam kehidupan masyarakat.

Karena itu setiap orang apakah muda secara biologis atau tua dalam bidang tertentu, sama sekali tidak bisa dipisahkan dengan pendidikan. Negara-negara yang masih tergolong negara berkembang, masih sangat meyakini bahwa pendidikan formal adalah pendidikan satu satunya yang dapat membentuk dan menanamkan nilai-nilai kepribadian yang diharapkan oleh para orang tua. Pendidikan dianggap terkorelasi secara aktif atau dinamis, untuk menggambarkan masa depan dan keselamatan anakanaknya. Pendidikan yang baik adalah pendidikan yang syarat dengan penguatan dimensi knowledge, cerdas dari segi ilmu pengetahuan. Dengan 
ilmunya dapat menemukan, mengembangkan teori sehingga muncul sebagai ilmuan. Meskipun pada dimensi lain hal tertentu ada yang dinafikan seperti manusia tidak diposisikan sebagai makhluk yang sempurna dengan memiliki kemampuan, pemahaman, penghayatan dan keterampilan.

Tidak bisa dinafikan bahwa dalam perkembangan kemajuan peradaban dan teknologi saat ini, peserta didik tidak siap menghadapi perubahan, dia bukan agen perubahan, maka anak didik adalah santapan paling empuk untuk merusak suatu bangsa. Sangat ramailah di dalam masyarakat, peserta didik melakukan tawuran, terlibat dalam kriminalitas, obat-obat terlarang, perkelahian, prostitusi dan lain sebagainya. Hal tersebut menurut hemat penulis adalah tempat pelarian bagi anak, karena potensi yang dimiliki, tidak mencapai puncak seperti yang diharapkan. Pendidikan Agama Islam yang ditransformasikan oleh para guru, berlalu begitu saja tanpa ada kesan. Belajar pendidikan agama tidak lebih dengan belajar matematika yang meninggalkan pengetahuan belaka sesudah tidak mengetahui perhitungan, perkalian, bagi dan seterusnya dianggap sebagai capaian maksimal dalam proses pendidikan.

Penyimpangan sosial yang dilanda oleh peserta didik, hari ini dan masa yang akan datang adalah merupakan refleksi dari kegagalan pemahaman terhadap pendidikan agama Islam. Ditempat anak menerima pendidikan tidak menyentuh aspek penghayatan dan kasadarannya. Apabila hal ini dicapai maka peserta didik akan sangat mampu menyaring perbuatan yang dapat merugikan dirinya, negara, dan agamanya. Akan terus menempatkan dirinya pada posisi hikmat dan kemanfaatan.terdapat beberapa alasan mengapa manusia harus dididik, Pertama, anak memiliki potensi. Seandainya seorang anak atau siapapun tidak memiliki potensi maka sudah pasti manusia tidak dapat dididik. Islam menegaskan bahwa manusia dilahirkan dengan membawa potensi sebagai modal dasar untuk dikembangkan pada bidang pengetahuan, keterampilan dan kepribadian, Kedua, Pengembangan fitrah manusia terkait dengan pelaksanaan pendidikan. Seandainya potensi manusia, dapat dikembangkan dengan sendirinya sesuai dengan kebutuhan kehidupan manusia yang bersangkutan tanpa memerlukan keterlibatan pendidik maka tidak diperlukan upaya pendidikan, Ketiga, Anak adalah amanat Allah yang harus dipertanggungjawabkan. Dalam Islam, anak bukan hanya sekedar konsekuensi dari pemenuhan kebutuhan biologis orang tua (ayah dan ibu), tetapi anak merupakan titipan Allah yang harus dipertanggungjawabkan kepada-Nya. Di antaranya adalah tanggung jawab mendidik, tugas memberikan pengetahuan, keterampilan dan kepribadian kepada anak yang bersangkutan. Posisi anak sebagai amanat Allah inilah antara lain yang menjadi faktor 
esensial harus dilaksanakannya pendidikan kepada mereka oleh para orang tua, sebab bila tidak, merupakan suatu pelanggaran terhadap ajaran Islam yang harus dipertanggungjawabkan kelak. Jadi mengapa anak harus dididik oleh orang tuanya (dalam arti luas), karena Allah menitipkan anak tersebut kepada orang tuanya untuk dididik, dipelihara, dan dibimbing yang merupakan tanggung jawab dan amanat terhadap Allah.

Manusia selain bisa dididik juga mendidik. Penulis ingin lebih menyederhanakan kata mendidik menjadi guru. Guru adalah orang yang memberikan ilmu pengetahuan kepada anak didik. Guru dalam pandangan masyarakat adalah orang yang melaksanakan pendidikan di tempat tertentu, tidak mesti dilembaga pendidikan formal, tetapi juga di masjid, mushallah, rumah dan sebagainya.

Dengan kepercayaan yang diberikan oleh masyarakat, maka guru diberikan tugas dan tanggung jawab yang besar. Sebab tanggung jawab guru tidak sebatas di sekolah saja, tetapi juga di luar sekolah. Pembinaan yang harus diberikan oleh guru tidak hanya pada kelompok tertentu tetapi juga secara individual. Hal tersebut menuntut guru agar selalu memperhatikan sikap, tingkah laku, dan perbuatan anak didiknya tidak hanya di lingkungan sekolah tetapi di luar sekalipun.

Guru sebagai profesi harus selalu didasarkan pada panggilan jiwa dan pengabdian. Maka bila guru melihat anak didiknya senang berkelahi, minum minuman keras, mengisap ganja, dan sebagainya, guru merasa sakit hati. Siang dan malam selalu memikirkan bagaimana caranya agar anak didiknya dapat dicegah dari perbuatan yang kurang baik.

Guru harus memiliki sifat-sifat tertentu yaitu; a) menerima dan mematuhi norma dan nilai-nilai kemanusiaan, b) memikul tugas mendidik dengan bebas, berani, dan gembira, c) sadar akan nilai-nilai yang berkaitan dengan perbuatan serta akibat-akibat yang ditimbulkan, d) bijaksana dan hati-hati (tidak nekat, tidak sembrono dan lain sebagainya, e) takwa terhadap Tuhan Yang Maha Esa." 21

Oleh karena itu guru bertangung jawab akan segala sikap, tingkah laku dan perbuatannya dalam rangka membina jiwa dan watak anak didik. Dengan demikian tanggung jawab guru adalah membentuk anak didik agar menjadi orang yang bersusila yang cakap dan berkepribadian mulia.

\section{KESIMPULAN}

1. Menuntun peserta didik terhadap perkembangan jiwa (pikiran, perasaan, kemauan, dan intuisi) dengan bahan materi dan metode tertentu dan dengan alat perlengkapan yang ada ke arah terciptanya pribadi tertentu. 
2. Membersihkan hati nurani dari penyakit hati seperti; sombong, congkak, dendam, iri hati dan sebagainya,

3. Mengisi nilai-nilai akhlak yang terpuji serperti: ikhlas, jujur, kasih sayang, tolong menolong, bersahabat, bersilaturrahmi, berkomunikasi dan saling mengingatkan

4. Manusia memiliki fitrah sebagai potensi diri

5. Manusia adalah makhluk yang didik menerima pengetahuan dan keterampilan untuk kepentingan dirinya, agama, dan masyarakatnya

6. Manusia dapat mendidik artinya dapat mentransformasi pengetahuan dan keterampilan yang dimilikinya.

\section{CATATAN AKHIR}

1. Djumberansjah Indar, Filsafat Pendidikan, Cet. I, Surabaya: Karya Abditama, 1994, h. 104.

2. Abuddin Nata, Manajemen Pendidikan, Ed I, Jakarta: Prenada Media; 2003, h.45.

3. W.J.S. Poerwadarminta, Kamus Umum Bahasa Indonesia, Cet. I, Jakarta: Balai Pustaka, 1991, h. 211.

4. Ibid, h. 46.

5. Daniel Goleman, Kecerdasan Emosi untuk Mencapai Puncak Prestasi, Cet. III, Jakarta: Gramedia Pustaka Utama, 2000, h. 9.

6. Ahmad D. Marimba, Pengantar Filsafat Pendidikan Islam, Cet. IV, Bandung: alMa'arif, 1980, h. 52.

7. Endang saefuddin Anshari, Pokok-pokok Pikiran Tentang Islam, Cet. IV, Jakarta: Usaha Interprise, 1976, h. 53.

8. Lihat Muhammad Hatta, Alam Pikiran Yunani, Jakarta: UI Press, 1986, h. 7.

9. Lihat Arnold Toynbee, Mankind and Mother Earth, terjemahan oleh Agung Prihantoro, Sejarah Umat Manusia, Cet. I, Yogyakarta: Pustaka Pelajar, 2007, h. 186.

10. Ibid, h. 29.

11. Abdul Rahman Shaleh, Psikologi suatu Pengantar dalam Persfektif Islam, Ed. I, Cet. I, Jakarta: Grenada Media, 2004, h. 54.

12. Ibnu Faris ibn Zakariyah, Mu'jam Maqayis al-Lughah, cairo: Maktabah Khanjiy, tt), h. 510 .

13. Abdul Majid, Nuansa-nuansa Psikologi Islam, Cet. I, Jakarta: Raja Grapindo Persada, 2001, h. 78.

14. Ibid, h. 84.

15. Ibid, h. 59.

16. Ibid, h. 60

17. Ibid, h. 80

18. Abdul Madjid, op. cit, h. 84 .

19. Ahmad Syar'i, Filsafat Pendidikan Islam, Jakarta: Pustaka Firdaus, 2005, h.40. 
20. Ibid, h. 43.

21. Saiful Bahri DJamarah, Guru dan Anak Didik, Jakarta: Rineka Cipta, 2005, h. 36.

\section{DAFTAR PUSTAKA}

Anshari, Endang Saefuddin, Pokok-pokok Pikiran Tentang Islam, Cet. IV, Jakarta: Usaha Interprise, 1976.

Azra, Azyumardi, Pendidikan Islam: Tradisi dan Medernitas Menuju Milenium Baru, Cet. I, Jakarta: Logos Wacana Ilmu, 1999.

Djamarah, Saiful Bahri, Guru dan Anak Didik, Jakarta: Rineka Cipta, 2005.

Goleman, Daniel, Kecerdasan Emosi untuk Mencapai Puncak Prestasi, Cet. III, Jakarta: Gramedia Pustaka Utama, 2000.

Hamdani, Filsafat Pendidikan, Cet. III, Yogyakarta: Kola Kembang, 1993.

Hatta, Muhammad, Alam Pikiran Yunani, Cet. III, Jakarta: UI Press, 1986.

Indar, Djumberansjah, Filsafat Pendidikan, Cet. I, Surabaya: Karya Abditama, 1994.

Jalaluddin, Filsafat Pendidikan, Cet. I, Jakarta: Gaya Media Pratama, 1997.

Jalaluddin, Filsafat Pendidikan, Manusia Filsafat dan Pendidikan, Cet. II, Jakarta: Gaya Media Pratama, 2002.

Majid, Abdul, Nuansa-nuansa Psikologi Islam, Cet. I, Jakarta: Raja Grapindo Persada, 2001.

Marimba, Ahmad D., Pengantar Filsafat Pendidikan Islam, Cet. IV, Bandung: alMa'arif, 1980.

Nata, Abuddin, Manajemen Pendidikan, Ed I, Jakarta: Prenada Media, 2003.

Poerwadarminta, W.J.S., Kamus Umum Bahasa Indonesia, Cet. I, Jakarta: Balai Pustaka, 1991.

Prasetya, Filsafata Pendidikan, Bandung: Pustaka setia, 1997.

Shaleh, Abdul Rahman, Psikologi suatu Pengantar dalam Persfektif Islam, Ed. I, Cet. I, Jakarta: Prenada Media, 2004.

Syar'i, Ahmad, Filsafat Pendidikan Islam, Jakarta: Pustaka Firdaus, 2005.

Toynbee, Arnold, Mankind and Mother Earth, terjemahan oleh Agung Prihantoro, Sejarah Umat: Manusia, Cet. I, Yogyakarta: Pustaka Pelajar, 2007.

Zakariyah, Ibn Faris, Mu'jam Maqayis al-Lughah, Cairo: Maktabah Khanjiy, tt. 